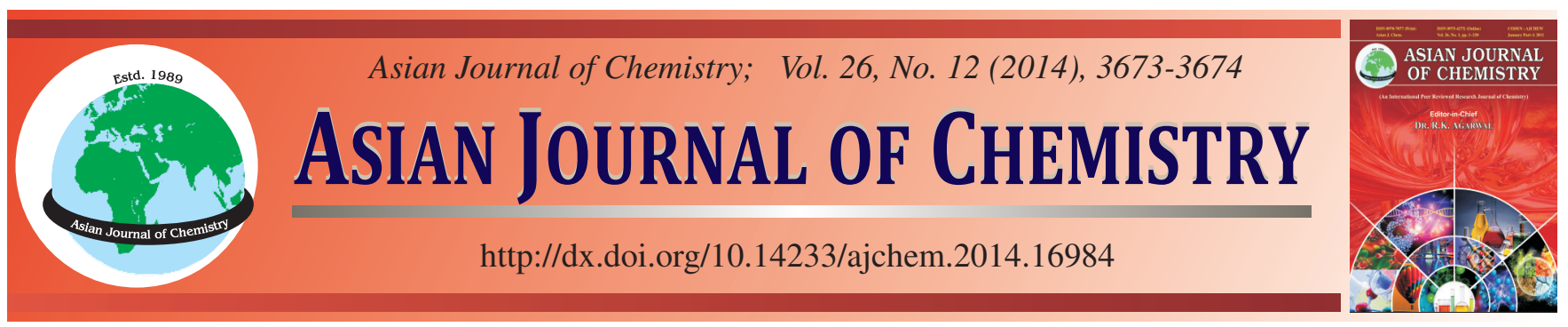

NOTE

\title{
Hydrothermal Synthesis and Crystal Structure of Thiophene-3,4-dicarboxylate Manganese(II)
}

\section{ZHANG ${ }^{1, *}$ and Y.X. $\mathrm{HE}^{2}$}

${ }^{1}$ College of Chemistry and Chemical Engineering, Luoyang Normal University, Henan, P.R. China

${ }^{2}$ College of Chemical Engineering and Pharmaceutics Henan University of Science and Technology, Henan, P.R. China

*Corresponding author: Tel/Fax: +86 379 65515113; E-mail: zhanglihxx@ 126.com

\begin{abstract}
A new manganese complex with formula $\mathrm{C}_{12} \mathrm{H}_{4} \mathrm{O}_{8} \mathrm{~S}_{2} \mathrm{Mn}_{2}$ is formed by the reaction of $\mathrm{Mn}(\mathrm{OAc})_{2} \cdot 4 \mathrm{H}_{2} \mathrm{O}$ and thiophene-3,4-dicarboxylic acid in presence of $\mathrm{KOH}$. The compound has been characterized by X-ray single-crystal diffraction, compound shows a one-dimensional framework. The 3D supramolecular structure is formed via hydrogen bonding connection.
\end{abstract}

Keywords: Coordination polymer, Crystal structure, Manganese(II).

Metal organic frameworks (MOFs) have received much attention in the field of crystal engineering and supramolecular chemistry because of their diverse structures and promising applications in functional materials such as luminescent materials, gas adsorption and magnetism ${ }^{1-4}$. Hydrogen bonds are well suited for the design of polymeric arrangement and crystal engineering because of their important directional interactions and because they can interlink 1-D, or 3-D structures into higher-dimensionality systems ${ }^{5,6}$.

All reagent and solvents employed were commercially available and used as received without further purification.

A mixture of $\mathrm{Mn}(\mathrm{OAc})_{2} \cdot 4 \mathrm{H}_{2} \mathrm{O}(0.25 \mathrm{mmol})$, thiophene3,4-dicarboxylic acid $(0.75 \mathrm{mmol})$ and $\mathrm{KOH}(0.25 \mathrm{mmol})$ and distilled water $(10 \mathrm{~mL})$ was heated in a $25 \mathrm{~mL}$ stainless steel reactor with a Teflon liner $403 \mathrm{~K}$ for $36 \mathrm{~h}$, followed by slow cooling to room temperature. Yellow crystals of the compound formed.

Detection method: Diffraction intensity data of the single crystal of the five compounds were collected on a Bruker SMART APEX-II CCD diffractometer equipped with a graphite monochromated $\mathrm{MoK}_{\alpha}$ radiation $(\lambda=0.71073 \AA$ ) by using a $\omega$-scan mode. All the structures were solved by direct methods and refined by full-matrix least-squares methods on $\mathrm{F}^{2}$ using the program SHEXL $97^{7}$. All non-hydrogen atoms were refined anisotropically. The hydrogen atoms were located by geometrically calculations and their positions and thermal parameters were fixed during the structure refinement. The crystallographic data and experimental details of structural analyses for coordination polymers are summarized in Table-1. Selected bond and angle parameters are listed in Table- 2 .

The molecular structure of $\mathrm{C}_{12} \mathrm{H}_{4} \mathrm{O}_{8} \mathrm{~S}_{2} \mathrm{Mn}_{2}$ is shown in Fig. 1.

X-ray diffraction analysis revealed that the fundamental building unit consists of metal manganese ion and thiophene3,4-dicarboxylic acid as bridging ligands to construct a new coordination polymer. On the thiophene ring, the hydrogen atoms were assigned with $\operatorname{Uiso}(\mathrm{H})=1.2 \mathrm{Ueq}(\mathrm{C})$ and included in the final refinement by using geometrical restraints, with

\begin{tabular}{ll}
\multicolumn{2}{c}{ TABLE-1 } \\
\multicolumn{1}{c}{ CRYSTALLOGRAPHIC DATA AND } \\
\multicolumn{1}{c}{ STRUCTURE REFINEMENT SUMMARY } \\
\hline Empirical formula & $\mathrm{C}_{12} \mathrm{H}_{4} \mathrm{O}_{8} \mathrm{~S}_{2} \mathrm{Mn}_{2}$ \\
Formula weight & 450.15 \\
Crystal system space group & Monoclinic, $\mathrm{C} 2 / \mathrm{c}$ \\
Unit cell dimensions & $\mathrm{a}=4.607(4) \AA ; \mathrm{b}=26.46(2) \AA$ \\
& $\mathrm{c}=6.124(5) \AA$ \\
Volume $\left(\AA^{3}\right)$ & $705.6(10)$ \\
$\theta$ range for data collection & $3.08-25.50$ \\
Final $\mathrm{R}$ indices $[\mathrm{I}>2 \sigma(\mathrm{I})]$ & $\mathrm{R}_{1}=0.0715 ; \mathrm{wR}_{2}=0.2051$ \\
$\mathrm{Z}$, calculated density $\left(\mathrm{mg} / \mathrm{m}^{3}\right)$ & $2,2.119$ \\
Absorption coefficient $\left(\mathrm{mm} \mathrm{m}^{-1}\right)$ & 2.127 \\
$\mathrm{~F}(000)$ & 444 \\
Limiting indices & $-5 \leq \mathrm{h} \leq 5 ;-32 \leq \mathrm{k} \leq 31 ;$ \\
& $-7 \leq 1 \leq 7$ \\
Largest diff. peak and hole $\left(\mathrm{e} / \AA^{3}\right)$ & 1.856 and -0.973 \\
Goodness-of-fit on $\mathrm{F}^{2}$ & 1.192 \\
$\mathrm{R}$ indices (all data) & $\mathrm{R}_{1}=0.0791, \mathrm{wR}_{2}=0.2173$ \\
\hline
\end{tabular}


TABLE-2

SELECTED BOND LENGTHS $(\AA)$ AND ANGLES $\left({ }^{\circ}\right)$

\begin{tabular}{|c|c|c|c|}
\hline$\overline{\mathrm{Mn}(1)-\mathrm{O}(2)}$ & $2.171(4)$ & $\mathrm{Mn}(1)-\mathrm{O}(2) \# 4$ & $2.253(5)$ \\
\hline $\mathrm{Mn}(1)-\mathrm{O}(1) \# 1$ & $2.128(4)$ & $\operatorname{Mn}(1)-\mathrm{O}(1) \# 2$ & $2.128(4)$ \\
\hline $\mathrm{O}(2) \# 3-\mathrm{Mn}(1)-\mathrm{O}(2) \# 5$ & $112.16(16)$ & $\mathrm{O}(2) \# 4-\mathrm{Mn}(1)-\mathrm{O}(2) \# 5$ & $169.5(2)$ \\
\hline $\mathrm{O}(2) \# 3-\mathrm{Mn}(1)-\mathrm{O}(2)$ & $81.8(2)$ & $\mathrm{O}(1) \# 1-\mathrm{Mn}(1)-\mathrm{O}(2) \# 4$ & $87.75(17)$ \\
\hline $\mathrm{O}(1) \# 1-\mathrm{Mn}(1)-\mathrm{O}(2)$ & $157.96(17)$ & $\mathrm{O}(2) \# 3-\mathrm{Mn}(1)-\mathrm{O}(2) \# 4$ & $76.19(17)$ \\
\hline $\mathrm{O}(1) \# 1-\mathrm{Mn}(1)-\mathrm{O}(2) \# 3$ & $94.57(18)$ & $\mathrm{O}(1) \# 2-\mathrm{Mn}(1)-\mathrm{O}(2) \# 4$ & $85.25(17)$ \\
\hline $\mathrm{O}(1) \# 1-\mathrm{Mn}(1)-\mathrm{O}(1) \# 2$ & $96.5(2)$ & $\mathrm{O}(1) \# 1-\mathrm{Mn}(1)-\mathrm{O}(2) \# 5$ & $85.25(17)$ \\
\hline
\end{tabular}
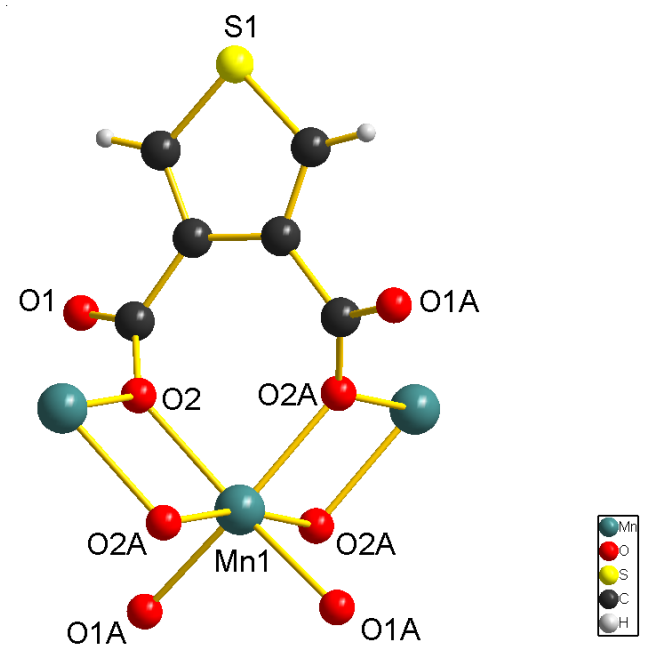

Fig. 1. Molecular structure of $\mathrm{C}_{12} \mathrm{H}_{4} \mathrm{O}_{8} \mathrm{~S}_{2} \mathrm{Mn}_{2}$ at $30 \%$ probability displacement ellipsoids

$\mathrm{d}(\mathrm{C}-\mathrm{H})=0.93 \AA$, The $\mathrm{C}-\mathrm{C}$ bonds within the thiophene are significantly shorter compared to tother $\mathrm{C}-\mathrm{C}$ bonds. The manganese atom is six-coordinated $\left[\mathrm{MnO}_{6}\right]$ in a distorted octahedral manner and two oxygen atoms $(\mathrm{O} 1$ and $\mathrm{O} 2)$ from thiophene-3,4- dicarboxylic acid ligands. The $\mathrm{Mn}-\mathrm{O}$ bond lengths are 2.128(4) $\AA$ and 2.171(4) $\AA$, respectively. The chains are further assembled by the intermolecular hydrogen bonding interaction leading to the formation of a 3D framework (Fig. 2).

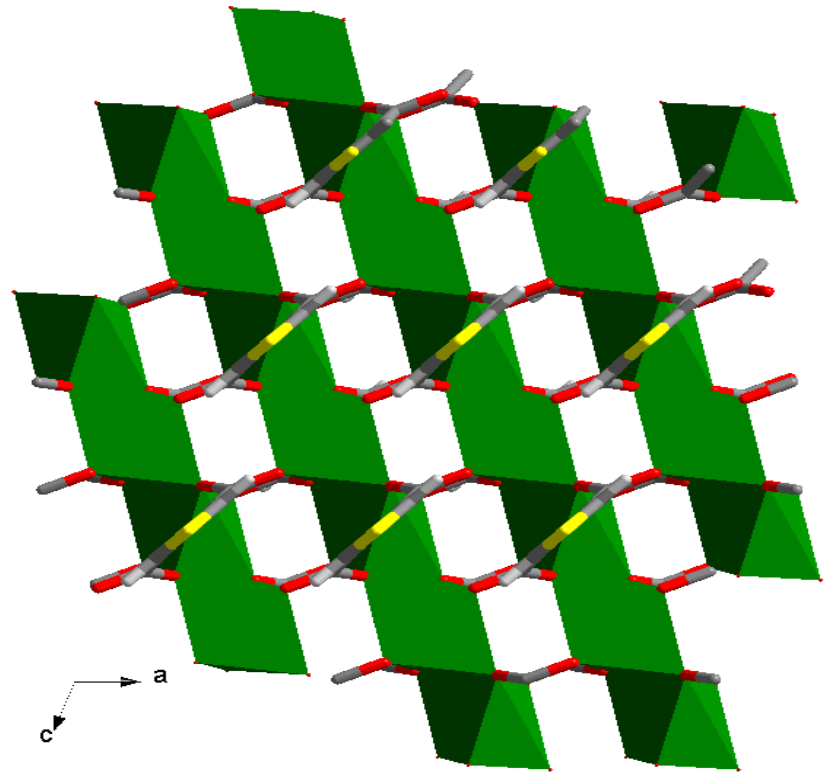

Fig. 2. 3D structure formed via hydrogen bonding interactions

\section{REFERENCES}

1. B.O. Patrick, C.L. Stevens, A. Storr and R.C. Thompson, Polyhedron, 24, 2242 (2005).

2. Y.H. Wen, J.K. Cheng, Y.L. Feng, J. Zhang, Z.L. Li and Y.G. Yao, Inorg. Chim. Acta, 358, 3347 (2005).

3. X.L. Wang, C. Qin, E.B. Wang and L. Xu, J. Mol. Struct., 749, 45 (2005).

4. $\quad$ S.R. Batten and K.S. Murray, Coord. Chem. Rev., 246, 103 (2003).

5. T.L. Hu, R.Q. Zou, J.R. Li and X.H. Bu, J. Chem. Soc., Dalton Trans., 1302 (2008).

6. J.F. Song, Y. Chen, Z.G. Li, R.S. Zhou, X.Y. Xu and J.Q. Xu, J. Mol. Struct., 842, 125 (2007).

7. G.M. Sheldrick, SHELXTL97, Program for the Refinement of Crystal Structure, University of Gottingen, Germany (1997). 